\title{
The Poly(ADP-ribose) polymerase inhibitors in pancreatic
}

\section{cancer}

\author{
Katarzyna Zubik¹, Julia Talaśka', Dawid Sigorski2, 3*, Sergiusz Nawrocki², 4* \\ Collegium Medicum, University of Warmia and Mazury in Olsztyn, Olsztyn, Poland \\ ${ }^{2}$ Department of Oncology, Collegium Medicum, University of Warmia and Mazury in Olsztyn, Olsztyn, Poland \\ ${ }^{3}$ Department of Oncology and Immuno-Oncology, Warmian-Masurian Cancer Center of The Ministry of The Interior \\ and Administration's Hospital, Olsztyn, Poland
}

${ }^{4}$ Department of Radiotherapy, Warmian-Masurian Cancer Center of The Ministry of The Interior and Administration's Hospital, Olsztyn, Poland

* co senior-authorship

Genome instability and mutations are the hallmarks of cancer. Mutations within BRCA genes increase the risk of pancreatic cancer (PC) development. Poly(ADP-ribose) polymerase inhibitors (PARPi) show the synthetic lethality phenomenon in tumoral cells with BRCA mutation and improve outcomes in patients with breast, prostate and ovarian cancer. Olaparib was the first PARPi registered for the patient with metastatic PC with a deleterious or suspected deleterious germline BRCA-mutation. The POLO phase III clinical trial shows that olaparib in PC increases progression-free survival, however it does not prolong the overall survival. Currently, many clinical trials are ongoing to determine the clinical utility of PARPi in monotherapy or polytherapy of PC. The role of PARPi in PC has not been well established and many questions remain unanswered. This review aims to summarise the rationales behind the use of PARPi and current clinical data.

Key words: PARP inhibitors, olaparib, pancreatic cancer, BRCA mutation

\section{Introduction}

It is estimated that 60,430 (31,950 men and 28,480 women) cases of pancreatic cancer (PC) will be diagnosed and 48,220 people (25,270 men and 22,950 women) will die in 2021 in the USA according to the American Cancer Society [1]. PC is the fourth leading cause of cancer death in men as well as women. The prognosis of PC is unfavorable and life expectancy is about $5 \%$ at 5 years [2]. The majority of patients at the time of diagnosis present unresectable tumours due to either local extension or distant metastases. The current treatment options for patients with metastatic PC include fibrinolysin, gemcitabine with nab-paclitaxel, or erlotinib regimens which significantly improved the clinical outcomes in comparison to gemcitabine monotherapy that was the standard therapy for many years $[3,4]$.

Advances in molecular biology and genetics allow designing poly(ADP-ribose) polymerase inhibitors (PARPi), which are a new class of drugs based on molecular profiling, including BRCA mutational status assessment. PARP belongs to a group of enzymes involved in DNA repair, which are activated by DNA damage $[5,6]$. It includes olaparib, niraparib, talazoparib and rucaparib. PARPi improved treatment outcomes in patients with breast, prostate and ovarian cancer [7-12].

Currently, they are being tested in monotherapy or polytherapy in PC and may potentially improve the therapeutic armamentarium for that population of patients. In December

\section{How to cite:}

Zubik K, Talaśka J, Sigorski D, Nawrocki S. The Poly(ADP-ribose) polymerase inhibitors in pancreatic cancer. NOWOTWORY J Oncol 2022; 72: 34-43. 
2019, the Food and Drug Administration (FDA) approved olaparib as a maintenance treatment for patients with deleterious or suspected deleterious germline BRCA-mutated metastatic pancreatic adenocarcinoma [13]. Recently, in the phase III POLO trial, it was shown that olaparib increases the median of progression-free survival (mPFS), however without improving the median of overall survival (mOS) [14]. Nevertheless, PARPi are a promising new class of drugs that need further studies. This review aims to summarise the preclinical and clinical data on PARPi in PC.

\section{The role of BRCA genes and BRCAness in PC}

One of the hallmarks of cancer is genomic instability which leads to DNA alterations and predisposes to cancer development [15]. Two types of genetic alterations which lead to tumorigenesis can be distinguished - germline mutations and somatic - a somatic acquired mutation that arises spontaneously as a result of environmental factors like smoking [16]. The majority of PC, approximately $80 \%$, do not have any associations with either positive family history, or inherited genetic causes. 5.2\% are associated with an inherited component without positive family history and about $8 \%$ of patients with PC have a positive family history [17]. The most common mutation is in the KRAS (Kirsten rat sarcoma virus) gene whereas germline and somatic mutations in genes $B R C A$ (breast cancer) 1/2, ATM (ataxia-teleangiesctasia mutated) and PALB2 (partner and localizer of BRCA2) occurs less common of cases [15]. The incidence of germline and somatic mutations in $\mathrm{PC}$ is presented in table I. BRCA1 and BRCA2 are proteins that are involved in DNA repair and transcriptional regulation in response to DNA damage. They also take part in replication fork protection and are important factors responsible for resistance to the activity of numerous nucleases, including MRE11, DNA2, EXO1 and
MUS81 [20, 21]. Importantly, both proteins are involved in the homologous recombination repair (HRR) process, in which a homologous DNA sequence is used to guide repair that results in restoring the DNA sequence to its original form [22, 23]. Cells with dysfunction in BRCA $1 / 2$ genes have deficits in HRR and must use less accurate mechanisms to repair double-strand breaks, increasing the risk of cancer development [24]. In unselected populations, a pathogenic mutation in $B R C A 1$ is found in less than $1 \%$ and BRCA2 mutation in up to $2 \%$ of PC cases [17]. Identifying the BRCA mutation status in patients is clinically relevant because the mutation provides the data on other possible cancer risks associated with the BRCA mutation, like breast, ovarian and prostate cancers. Additionally, identifying the BRCA mutation status allows for testing at-risk family members for the same mutation with limited cost [25].

The mOS of patients with PC and BRCA1 and BRCA2 mutations is approximately 15 and 13 months, respectively [24]. Among approximately 13 hereditary genes associated with PC development, BRCA1 and 2 mutations are the most frequent genetic alteration responsible for $F P C$, which are diagnosed in $2.7 \%$ of patients with PC [17]. It has been reported that in about 3,9\% of unselected patients, somatic BRCA1/2 mutations drive the $P C$ [28]. The mOS for patients who carry mutations in HRR genes (ATM, BARD1 [BRCA1-associated RING domain protein 1], BRCA1, BRCA2, BRIP1 [BRCA1 interacting protein 1], PALB2, RAD51C, RAD51D) associated with $P C$ is 14.6 months, whereas mOS for patients without mutations was 11.7 months [26].

Apart from BRCA1/2 mutations, the other mutations related to $P C$ are alterations within other HRR genes like ATM, CDKN2A (cyclin-dependent kinase inhibitor 2a), MLH1 (mutL homolog 1) [17]. As opposed to breast cancer and prostate cancer, mutations in CHEK2 (checkpoint kinase 2) and PALB2 have no si-

Table I. The incidence of germline and somatic mutations in PC

\begin{tabular}{|c|c|c|c|c|c|}
\hline $\begin{array}{l}\text { Gene - germline } \\
\text { mutation }\end{array}$ & Incidence in PC & $\begin{array}{c}\text { Incidence in patients with } \\
\text { a positive family history } \\
\text { of PC }\end{array}$ & Gene - somatic mutation & $\begin{array}{l}\text { Incidence } \\
\text { in PC }\end{array}$ & Reference \\
\hline $\begin{array}{l}B R C A 1 \\
B R C A 2 \\
P A L B 2\end{array}$ & $\begin{array}{c}2.4 \% \\
26.2 \% \\
2.4 \%\end{array}$ & $\begin{array}{l}- \\
- \\
-\end{array}$ & $\begin{array}{c}\text { KRAS } \\
\text { TP53 } \\
\text { SMAD4 } \\
\text { CDKN2A } \\
\text { SMARCB1 } \\
\text { RB1 }\end{array}$ & $\begin{array}{c}88.1 \% \\
33.3 \% \\
16.7 \% \\
4.8 \% \\
2.4 \% \\
2.4 \%\end{array}$ & {$[73]$} \\
\hline $\begin{array}{l}\text { ATM } \\
\text { BRCA1 } \\
\text { BRCA2 } \\
\text { PALB2 } \\
\text { RAD51 }\end{array}$ & $\begin{array}{l}2.1 \% \\
0.6 \% \\
2.2 \% \\
0.4 \% \\
0.2 \%\end{array}$ & $\begin{array}{l}- \\
- \\
- \\
-\end{array}$ & - & - & {$[26]$} \\
\hline $\begin{array}{l}\text { ATM } \\
\text { BRCA1 } \\
\text { BRCA2 } \\
\text { CDKN2A } \\
\text { MSH2 } \\
\text { PALB2 }\end{array}$ & $\begin{array}{l}2.6 \% \\
0.7 \% \\
3.6 \% \\
1.3 \% \\
0.3 \% \\
0.3 \%\end{array}$ & $\begin{array}{l}3.2 \% \\
1.1 \% \\
4.3 \% \\
2.2 \% \\
0.5 \% \\
0.5 \%\end{array}$ & - & - & {$[33]$} \\
\hline
\end{tabular}


gnificant correlation to pancreatic cancer $[17,29]$. The mOS for patients treated with FOLFIRINOX chemotherapy in metastatic $P C$, who have somatic or germline mutations in BRCA1, BRCA2, PALB2, MSH2, FANC (the Fanconi anemia) complementation group was 14 months in comparison to 5 months in patients without mutations [30].

BRCAness is a phenomenon referred to as the existence of a HRR defect despite the absence of a germline BRCA1/2 mutation in tumour, which leads to oversensitivity to DNA damage as a result of increased genomic instability. The most common mutation in the HRR repair gene that contributes to the BRCAness phenotype is a somatic defect in BRCA1 and $B R C A 2$, however, BRCAness is also related to other genes involved in HRR, such as ATM, PALB2, ATR (ataxia teleangiectasia and Rad3 related), CHEK1/2, RAD51, NBS1 (Nijmegen breakage syndrome) and FANC family of genes [19, 31]. The incidence of HRR mutations in PC is shown in table II.

The data describing the role of genes other than BRCA are limited. Among the HRR genes, one of the most relatively known mutations related to inherited and sporadic PC is the ATM mutation [32]. The incidence of ATM mutations in patients with a positive family history of PC is approximately 3.2\% [30]. ATM serine/threonine kinase controls cells'survival, death, cell cycle arrest, apoptosis and DNA repair. Pathogenic germline ATM mutation increases the risk of PC [34-37]. However, ATM mutational status may be also important in predicting radiation and chemotherapy response $[38,39]$. ATM-deficient PC cells are more sensitive to fractionated radiation than wild-type pancreatic cancer [38]. ATM-mutated PC cells treated with olaparib significantly enhance suppression of the PC proliferation in vivo and in vitro [40].

Furthermore, it has been demonstrated that tumours with BRCAness have similar therapeutic vulnerability as tumours with germline BRCA gene mutations. For that reason, it is considered as a potentially significant factor in PARPi therapy [41,42].

Table II. Frequency of BRCAness mutations among patients with a positive family history of PC [17]

\begin{tabular}{|lc|}
\hline BRCAness & Prevalence in PC \\
\hline BRCA1 & $0.6 \%$ \\
\hline BRCA2 & $2.10 \%$ \\
\hline ATM & $3.29 \%$ \\
\hline PALB2 & $0.6 \%$ \\
\hline ATR & - \\
\hline CHEK1 & - \\
\hline CHEK2 & $2.4 \%$ \\
\hline RAD51 & $0 \%$ \\
\hline NBS1 & $0.3 \%$ \\
\hline FANC & $0.3 \%$ \\
\hline
\end{tabular}

\section{DNA damage response and PARP involvement in synthetic lethality}

DNA damage occurs constantly in cells due to exogenous and endogenous stressors leading to genome instability. DNA damage response (DDR) is a central mechanism responsible for detecting DNA lesions and promoting their swift repair. In the process of DDR, a great amount of different intra- and extracellular signalling pathways and enzyme activities are activated. In suboptimal or lack of activity of DDR, an exaggerated level of genomic instability arises - a characteristic feature of cancers. In human cells, two major forms of DNA damage could occur, either a single-strand break (SSB) or double-strand breaks (DSB), whereby SSB occurs more often. Different forms of DNA damage bring responses by proper signalling pathways and repair mechanisms [43, 44]. There are four known repair pathways involved in SSB: base excision repair (BER), nucleotide excision repair (NER), mismatch repair (MMR) and trans-lesional synthesis. HRR and non-homologous end joining (NHEJ) are two pathways responsible for repair DSBs. The HRR process involves BRCA1/2, PALB2, ATM, RAD51, CHEK1/2, ATR, p53 proteins and MRN complex composed of Mre11, Rad50 and NBS1/NBN proteins [45-47]. When DSB occurs, it is detected by the MRN complex and the ATM and ATR - the cell cycle regulatory kinases are activated. Subsequently, ATM activates CHK2, which arrests cell cycle progression, contributes to regulating BRCA1 in DNA repair, and interacts with TP53, which is responsible for cell cycle and apoptosis control. The MRN complex also recruits BRCA1/2 and PALB2 to the DNA damage site. These proteins form a new complex, which finally activates RAD51 that is responsible for binding single-stranded DNA segments and invading the homologous sequences in the sister chromatid.

PARP enzymes are known as DNA damage sensors. This nuclear deoxyribonucleic acid-binding protein contains an N-terminal double zinc-finger DNA-binding domain, a nuclear localization signal, a central automodification and a C-terminal catalytic domain. Its basal enzymatic activity is low but the variety of allosteric activators, for example, damaged DNA, nucleosomes and a variety of protein-binding partners, strongly stimulates it. When SSBs occur, the PARP enzymes are activated and binds to the site of single-DNA damage using its zinc-finger DNA-binding domain. It cleaves NAD+ into nicotinamide and ADP-ribose. The latter cleavage product is covalently attached to glutamate or aspartate residues of nuclear acceptor proteins in the form of long branching ADP-ribose polymers. This results in a highly negatively charged polymer and subsequently leads to the unwinding and repair of the damaged DNA through the BER [48-52]. PARPi interfere with base excision repair by binding to the catalytic domain of PARP, which prevents PARylation, traps PARP to the SSB, and prevents repair. Consequently, an accumulation of SSB occurs, which degenerate into DNA DBS. As a result, cancer cells undergo cell cycle arrest and apoptosis when exposed to these agents. 
Inhibition of PARP-1 in PC cells increases the caspase-3 activity, and by increasing the $\mathrm{p} 53$ protein expression suppresses $\mathrm{BCL}-2$ (B-cell lymphoma 2), as a consequence leading to apoptosis and suppression of PC cell proliferation [53]. Except for SSB, in cells PARP enzymes also take part in HRR-mediated DSB repair [54]. Inhibition of these enzymes in cancer cells could cause cell death which is based on a phenomenon called synthetic lethality (fig. 1). It is defined as the situation when two or more separate genes are simultaneously mutated which lead to cell death. The product of one of these genes is crucial to the survival of the cell, whereas another gene is used as an alternative. In a situation when the gene is mutated, it is replaced by a second one that is involved in an alternative pathway of the same process. In cells with BRCA biallelic mutation, cells become incapable to properly perform HRR. In case of DNA damage, these disorders are repaired with PARP and BER repair. The use of olaparib in the presence of the mutation disrupts

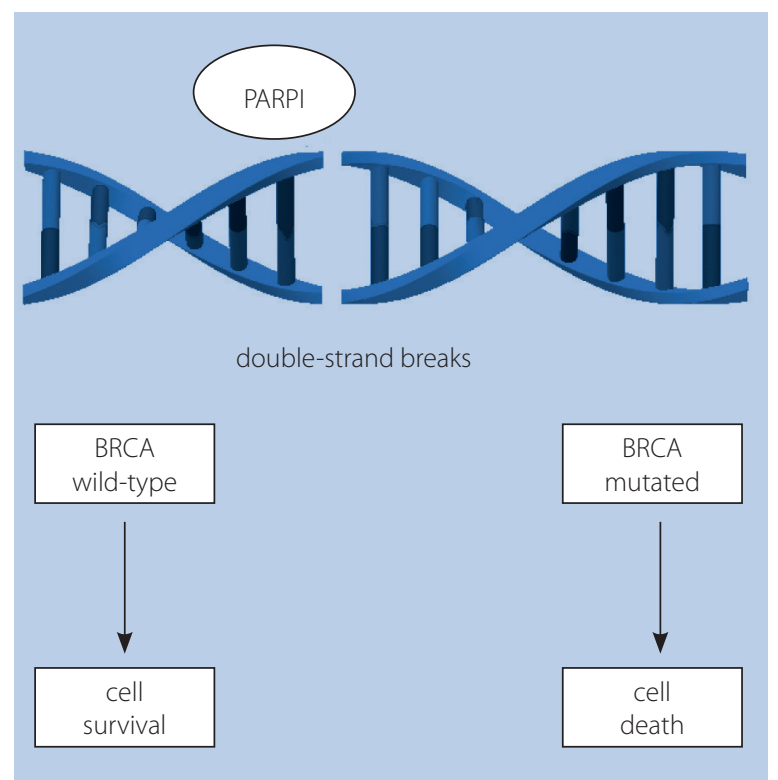

Figure 1. Synthetic lethality and PARPi both repair mechanisms, leading to cell death, because inhibition of PARP activity leads to the accumulation of single-strand breaks, which can lead to double-strand breaks properly repaired by HRR [55-58]. The synthetic lethality in BRCA-mutated cancers caused by selective inactivation of PARP enzymes cells are unable to successfully repair DNA damaged, which consequently cause its death $[59,60]$.

\section{Pathobiology of PC}

The expression and localization of PARP-1 in the pancreas and $P C$ are different. In the human pancreas, only nuclear PARP-1 (nPARP-1) expression was shown, contrary to nPARP-1 and cytoplasmic PARP-1 (CPARP-1) expression in PC. In the pancreas, the expression of nPARP-1 is enough to maintain the cell's homeostasis by triggering apoptosis in response to DNA damage due to its proapoptotic activity; whereas in PC tissue, the lower expression of nPARP-1 prevents it. PARP-1 takes part in regulating TRAIL (TNF-related apoptosis-inducing ligand) induced apoptosis. Inhibition of PARP-1 may sensitize TRAIL resistant PC cells to TRA-8-induced apoptosis [57]. PARP expression was studied as a new potential prognostic factor in PC. Immunohistochemical analysis of CPARP and nPARP among 178 PC show that high nPARP was associated with a better prognosis (mOS14.5 vs. 9.6 months, $p=0.004$ ), however, it did not show a statistically significant correlation with clinicopathological parameters [61]. FeiXu et al. in their studies focused on CPARP-1 and compared the frequency of CPARP-1 in well, moderately and poorly differentiated PC. Initially, they suggest potential relations between CPARP-1 expression on PC pathogenesis and progression, similar to recent breast cancer reports where the correlation between aggressiveness, higher risk of relapse and the death of patients were seen $[57,62]$. In their studies, the expression of CPARP-1 was higher in moderately and poorly differentiated than well-differentiated pancreatic tumours. Furthermore, they linked PARP-1 in the cytoplasm to the extrinsic pathway of apoptosis [57].

Table III. Ongoing trials with PARPi in monotherapy in patients with PC

\begin{tabular}{|c|c|c|c|c|c|c|c|}
\hline $\begin{array}{l}\text { Name of the } \\
\text { study }\end{array}$ & Phase & $\begin{array}{l}\text { Indication/ } \\
\text { tumour type }\end{array}$ & Study drug & Control arm & $\begin{array}{l}\text { Mutational } \\
\text { status }\end{array}$ & $\begin{array}{l}\text { Primary } \\
\text { outcome measure }\end{array}$ & $\begin{array}{l}\text { Secondary outcome } \\
\text { measure }\end{array}$ \\
\hline NCT04005690 & early I & stage I-IV PC & olaparib & cobimetinib & - & $\begin{array}{l}\text { proportion of all } \\
\text { feasibility - evaluable } \\
\text { participants that have } \\
\text { a measurable change } \\
\text { in post-treatment } \\
\text { tumour biology from } \\
\text { baseline }\end{array}$ & $\begin{array}{l}\text { - incidence of } \geq \text { grade } \\
3 \text { toxicities for each } \\
\text { assigned window } \\
\text { treatment } \\
\text { - proportion of feasibility } \\
\text { - evaluable participants } \\
\text { within each study arm that } \\
\text { have a measurable change } \\
\text { in post-treatment tumour } \\
\text { biology from baseline }\end{array}$ \\
\hline NCT01078662 & $\|$ & $\begin{array}{l}\text { ovarian, breast, } \\
\text { prostate, } \\
\text { pancreatic } \\
\text { advanced tumours }\end{array}$ & olaparib & - & $\begin{array}{l}\text { BRCA1/2 } \\
\text { mutation }\end{array}$ & tumour response rate & $\begin{array}{ll}\cdot & \mathrm{ORR}^{*} \\
\cdot & \mathrm{PFS} \\
\cdot & \mathrm{OS} \\
\cdot & \text { duration of response }\end{array}$ \\
\hline
\end{tabular}


Table III. cont. Ongoing trials with PARPi in monotherapy in patients with PC

\begin{tabular}{|c|c|c|c|c|c|c|c|}
\hline $\begin{array}{l}\text { Name of the } \\
\text { study }\end{array}$ & Phase & $\begin{array}{l}\text { Indication/ } \\
\text { tumour type }\end{array}$ & Study drug & Control arm & $\begin{array}{l}\text { Mutational } \\
\text { status }\end{array}$ & $\begin{array}{l}\text { Primary } \\
\text { outcome measure }\end{array}$ & $\begin{array}{l}\text { Secondary outcome } \\
\text { measure }\end{array}$ \\
\hline $\begin{array}{l}\text { NCT02184195 } \\
\text { (POLO) }\end{array}$ & III & PC & olaparib & placebo & $\begin{array}{l}\text { germline } \\
\text { BRCA1/2 } \\
\text { mutation }\end{array}$ & PFS & $\begin{array}{l}\text { - OS } \\
\text { - time from randomisation } \\
\text { to second progression } \\
\text { - time from randomisation } \\
\text { to first and second } \\
\text { subsequent therapy or } \\
\text { death } \\
\text { - ORR* } \\
\text { - quality of life (QoL) } \\
\text { - } \text { AEs }\end{array}$ \\
\hline NCT02677038 & $\|$ & metastatic PC & olaparib & - & $\begin{array}{l}\text { - mutation } \\
\text { in germline } \\
\text { BRCA1/2 } \\
\text { negative } \\
\text { - BRCAness } \\
\text { pheno-type }\end{array}$ & ORR* & $\begin{array}{l}\text { - } \text { OS } \\
\text { - } \text { PFS } \\
\text { - change in CA19-9 } \\
\text { - } \text { AEs }\end{array}$ \\
\hline $\begin{array}{l}\text { NCT04858334 } \\
\text { (APOLLO) }\end{array}$ & $\|$ & resectable PC & olaparib & - & BRCA1/2, PALB2 & $\begin{array}{l}\text { improvement in } \\
\text { relapse-free survival }\end{array}$ & $\begin{array}{l}\cdot \text { RFS } \\
\cdot \text { OS } \\
\cdot \text { - efficacy after chemotherapy } \\
\text { - } \text { differences in survival }\end{array}$ \\
\hline NCT03601923 & $\|$ & advanced PC & niraparib & - & $\begin{array}{ll}\cdot & B R C A 1 \\
\cdot & B R C A 2 \\
\cdot & \text { PALB2 } \\
\cdot & \text { CHEK2 or ATM } \\
& \text { mutation }\end{array}$ & PFS & $\begin{array}{l}\text { - } O R R^{* *} \\
\text { - } O S R \\
\text { - } A E S\end{array}$ \\
\hline $\begin{array}{l}\text { NCT04171700 } \\
\text { (LODESTAR) }\end{array}$ & $\|$ & solid tumours & rucaparib & - & 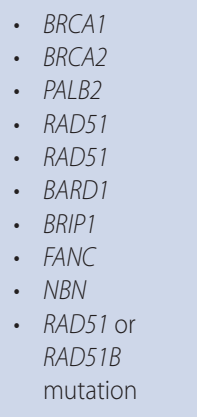 & best $O R R^{* *}$ & $\begin{array}{l}\text { - } \mathrm{ORR}^{* *} \\
\text { - } \mathrm{PFS} \\
\text { - } \mathrm{AES}\end{array}$ \\
\hline NCT03140670 & $\|$ & $\begin{array}{l}\text { metastatic locally } \\
\text { advanced PC }\end{array}$ & rucaparib & - & $\begin{array}{l}\text { BRCA1/2 or PALB2 } \\
\text { mutation }\end{array}$ & AEs & - \\
\hline NCT04550494 & $\|$ & $\begin{array}{l}\text { malignant solid } \\
\text { neoplasm } \\
\text { including PC }\end{array}$ & talazoparib & - & $\begin{array}{l}\text { germline or } \\
\text { somatic aberra- } \\
\text { tions in genes } \\
\text { involved in } \\
\text { DNA damage } \\
\text { response }\end{array}$ & $\begin{array}{l}\text { percent of patients } \\
\text { who demonstrate } \\
\text { simultaneous Rad51 } \\
\text { activation }\end{array}$ & $\begin{array}{l}\text { - } \mathrm{ORR}^{* *} \\
\text { - tumour genomic } \\
\text { alterations potentially } \\
\text { associated with sensitivity } \\
\text { to talazoparib }\end{array}$ \\
\hline NCT04182516 & । & $\begin{array}{l}\text { - locally } \\
\text { advanced/ } \\
\text { metastatic } \\
\text { HER2 negative } \\
\text { breast cancer } \\
\text { - epithelial } \\
\text { ovarian cancer } \\
\text { - castration- } \\
\text { resistant } \\
\text { prostate cancer } \\
\text { - PC }\end{array}$ & $\begin{array}{c}\text { NMS } \\
-03305293\end{array}$ & - & - & $\begin{array}{l}\text { number of } \\
\text { participants with first- } \\
\text { cycle dose-limiting } \\
\text { toxicity }\end{array}$ & AEs \\
\hline
\end{tabular}

$A E$ - adverse events; ORR* - objective response rate; $O R R^{* *}$ - overall response rate; OS - overall survival; OSR - overall survival rate; $P C$ - pancreatic cancer; PFS - progression free survival; RFS - relapse-free survival 
Table IV. Ongoing clinical trials with PARPi in polytherapy

\begin{tabular}{|c|c|c|c|c|c|c|c|}
\hline $\begin{array}{l}\text { Name of the } \\
\text { study }\end{array}$ & $\begin{array}{l}\text { Pha- } \\
\text { se }\end{array}$ & Tumour type & $\begin{array}{l}\text { Experimenta- } \\
\text { larm }\end{array}$ & Control arm & $\begin{array}{l}\text { Mutational } \\
\text { status }\end{array}$ & $\begin{array}{l}\text { Primary outcome } \\
\text { measures }\end{array}$ & $\begin{array}{l}\text { Main secondary } \\
\text { outcome measures }\end{array}$ \\
\hline NCT02498613 & $\|$ & $\begin{array}{ll}\text { - } & \text { PC } \\
\text { - } & \text { lung cancer } \\
\text { - } & \text { breast cancer }\end{array}$ & $\begin{array}{l}\text { olaparib + } \\
\text { cediranib }\end{array}$ & - & - & $\mathrm{ORR}^{*}$ & $\begin{array}{l}\text { - } \text { AES } \\
\text { - PFS }\end{array}$ \\
\hline NCT03682289 & $\|$ & $\begin{array}{l}\text { - } \text { PC } \\
\text { - } \text { renal cell } \\
\text { carcinoma } \\
\text { - urothelial } \\
\text { carcinoma } \\
\text { - other solid } \\
\text { tumours }\end{array}$ & $\begin{array}{l}\text { olaparib + } \\
\text { AZD6738 }\end{array}$ & AZD6738 & - & $\begin{array}{l}\text { - } \text { ORR }^{*} \\
\text { - composite prostate } \\
\text { cancer } \\
\text { - } \text { patient response } \\
\text { - } \text { rate ORR for other solid } \\
\text { tumours }\end{array}$ & $\begin{array}{l}\text { - } \text { DOR } \\
\text { - } \mathrm{PFS} \\
\text { - } \mathrm{AES}\end{array}$ \\
\hline NCT04548752 & $\|$ & metastatic PC & $\begin{array}{l}\text { olaparib + } \\
\text { pembrolizumab }\end{array}$ & olaparib & $\begin{array}{l}\text { germline } \\
\text { mutation in } B R C A \\
1 / 2\end{array}$ & PFS & $\begin{array}{ll}\text { - } & \text { AES } \\
\text { - } & \text { OS } \\
\text { - } & O R R^{* *}\end{array}$ \\
\hline NCT04493060 & $\|$ & $\begin{array}{l}\text { metastatic PDAC } \\
\text { pancreatic cancer }\end{array}$ & $\begin{array}{l}\text { niraparib + } \\
\text { dostarlimab }\end{array}$ & - & $\begin{array}{l}\text { - } \quad \text { BRCA1/2 } \\
\text { - } P A L B 2\end{array}$ & DCR - 12 weeks & $\begin{array}{l}\text { - } \text { ORR }^{*} \\
\text { - } \text { time to next } \\
\text { treatment } \\
\text { - } \text { OS } \\
\text { - } \text { PFS and AEs }\end{array}$ \\
\hline NCT04673448 & 1 & $\begin{array}{l}\text { - } \text { PC } \\
\text { - } \text { breast cancer } \\
\text { - } \text { ovarian cancer } \\
\text { - } \text { fallopian tube or } \\
\text { primary peritoneal } \\
\text { cancer }\end{array}$ & $\begin{array}{l}\text { niraparib + } \\
\text { dostarlimab }\end{array}$ & - & $\begin{array}{l}\text { mutation in } \\
B R C A 1 \text { or } B R C A 2\end{array}$ & best objective response & $\begin{array}{l}\text { - } \text { Aes } \\
\text { - } P F S \\
\text { - } \text { DOR } \\
\text { - } \text { DCR } \\
\text { - OS }\end{array}$ \\
\hline $\begin{array}{l}\text { NCT03404960 } \\
\text { (Parpvax) }\end{array}$ & |/II & $\begin{array}{l}\text { PC after platinum- } \\
\text { based therapy }\end{array}$ & $\begin{array}{l}1: \text { niraparib + } \\
\text { nivolumab }\end{array}$ & $\begin{array}{l}\text { niraparib + } \\
\text { ipilimumab }\end{array}$ & - & PFS & $\begin{array}{l}\text { - the proportion of } \\
\text { tumours with HRD, } \\
\text { ORR*, DOR, OS, AEs } \\
\text { - Immune activation } \\
\text { prior/ during } \\
\text { treatment }\end{array}$ \\
\hline NCT03337087 & $|/| \mid$ & metastatic PC & $\begin{array}{l}\text { rucaparib + } \\
\text { irinotecan } \\
\text { liposome }+ \\
\text { leucovorin }+ \\
\text { fluorouracil }\end{array}$ & - & $\begin{array}{l}\text { selected (BRCA1 } \\
\text { or BRCA2 or } \\
\text { PALB2 mutation) } \\
\text { and unselected }\end{array}$ & $\begin{array}{l}\text { - number of participants } \\
\text { with dose-limiting } \\
\text { toxicities } \\
\text { - objective response } \\
\text { - best response rate }\end{array}$ & $\begin{array}{ll}\text { - } & \text { DCR } \\
\text { - } & \text { OS } \\
\text { - } & \text { PFS } \\
\text { - } & \text { AE }\end{array}$ \\
\hline NCT02890355 & $\|$ & metastatic PC & $\begin{array}{l}\text { veliparib + } \\
\text { mFOLFIRI }\end{array}$ & FOLFIRI & - & OS & $\begin{array}{l}\text { - } \text { AES } \\
\text { - } P F S \\
\text { - } O R R^{*} \\
\text { - } \text { DCR }\end{array}$ \\
\hline NCT01585805 & $\|$ & $\begin{array}{l}\text { - } \text { metastatic PC } \\
\text { - } \text { recurrent PC } \\
\text { - stage IIIPC }\end{array}$ & $\begin{array}{l}\text { 1: veliparib + } \\
\text { gemcitabine + } \\
\text { cisplatin } \\
\text { 2: veliparib }\end{array}$ & $\begin{array}{l}\text { gemcitabine } \\
+ \text { cisplatin }\end{array}$ & $\begin{array}{l}\text { BRCA1/2 or PALB2 } \\
\text { mutation }\end{array}$ & $\begin{array}{l}\text { - the optimal dose of } \\
\text { drugs } \\
\text { - the response rate } \\
\text { to gemcitabine } \\
\text { hydrochloride and } \\
\text { cisplatin with versus } \\
\text { without veliparib } \\
\text { - response rate of single- } \\
\text { agent veliparib }\end{array}$ & $\begin{array}{l}\text { - } \text { PFS } \\
\text { - Aes } \\
\text { - DCR } \\
\text { - OS }\end{array}$ \\
\hline NCT00576654 & I & $\begin{array}{l}\text { metastatic tumours } \\
\text { or tumours that } \\
\text { cannot be removed } \\
\text { by surgery }\end{array}$ & $\begin{array}{l}\text { veliparib + } \\
\text { irinotecan }\end{array}$ & - & & $\begin{array}{l}\text { - } \text { optimal biologic dose } \\
\text { dose of study drugs } \\
\text { - maximally tolerated } \\
\text { dose } \\
\text { - recommended phase } \\
\text { Il dose }\end{array}$ & $\begin{array}{l}\text { - } \mathrm{AE} \\
\text { - tumour response }\end{array}$ \\
\hline NCT04228601 & $\mid \mathrm{b} / \mathrm{I}$ & advanced PC & $\begin{array}{l}\text { fluzoparib + } \\
\text { mFOLFIRINOX }\end{array}$ & $\begin{array}{l}\text { placebo + } \\
\text { mFOLFIRI- } \\
\text { NOX }\end{array}$ & $\begin{array}{l}\text { mutation } \\
\text { in germline } \\
B R C A 1 / 2 \text { or } P A L B 2\end{array}$ & $\begin{array}{l}\text { - number of participants } \\
\text { with a dose limited } \\
\text { toxicity } \\
\text { - maximum tolerated } \\
\text { dose } \\
\text { - ORR* }\end{array}$ & $\begin{array}{l}\text { - } \text { AES } \\
\text { - } \text { DCR } \\
\text { - OS } \\
\text { - PFS }\end{array}$ \\
\hline
\end{tabular}


Table IV. cont. Ongoing clinical trials with PARPi in polytherapy

\begin{tabular}{|c|c|c|c|c|c|c|c|}
\hline $\begin{array}{l}\text { Name of the } \\
\text { study }\end{array}$ & $\begin{array}{l}\text { Pha- } \\
\text { se }\end{array}$ & Tumour type & $\begin{array}{l}\text { Experimenta- } \\
\text { larm }\end{array}$ & Control arm & $\begin{array}{l}\text { Mutational } \\
\text { status }\end{array}$ & $\begin{array}{l}\text { Primary outcome } \\
\text { measures }\end{array}$ & $\begin{array}{l}\text { Main secondary } \\
\text { outcome measures }\end{array}$ \\
\hline $\begin{array}{l}\text { NCT04644068 } \\
\text { (PETRA) }\end{array}$ & 1 & $\begin{array}{l}\text { PC } \\
\text { ovarian cancer } \\
\text { breast cancer } \\
\text { prostate cancer }\end{array}$ & AZD5305 & $\begin{array}{l}\text { AZD5305 + } \\
\text { paclitaxel } \\
\text { AZD5305 + } \\
\text { carboplatin } \\
\text { with or } \\
\text { without } \\
\text { paclitaxel }\end{array}$ & - & $\begin{array}{l}\text { - the number of subjects } \\
\text { with adverse events/ } \\
\text { serious adverse events } \\
\text {. the number of subjects } \\
\text { with dose-limiting } \\
\text { toxicity }\end{array}$ & $\begin{array}{l}\cdot \text { ORR* } \\
\text {. } \mathrm{PFS}\end{array}$ \\
\hline NCT04503265 & $|/| \mid$ & 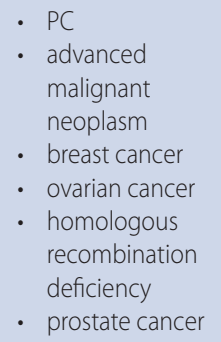 & AMXI-5001 & - & - & maximum-tolerated dose & $\begin{array}{l}\text { recommended phase } \\
2 \text { dose }\end{array}$ \\
\hline
\end{tabular}

$A E$ - adverse events; DCR - disease control rate; DOR - duration of response; $H R D$ - homologous recombination deficits; ORR* - objective response rate; ORR** - overall response rate; OS - overall survival; PC - pancreatic cancer; PFS - progression free survival

\section{The results of clinical trials in patients with PC}

Currently, the PARPi (olaparib, niraparib, rucaparib and talazoparib) are being tested in monotherapy (tab. III) and polytherapy (tab. IV) on different stages of PC, however, the results of clinical trials are limited. Olaparib remains the most studied drug.

The NCT01078662, phase II trial assessed the efficacy of olaparib in 298 patients with many solid tumours, including PC. 23 patients with PC were enrolled. 74\% of them had the BRCA2 mutation. The primary outcome measure was the tumour response rate. The main secondary outcome measure was the objective response rate, progression-free survival (PFS) and overall survival (OS). Eligible patients had a deleterious or suspected deleterious germline BRCA mutation. The tumour response rate in the $\mathrm{PC}$ was $21.7 \%$ (5-23; $95 \% \mathrm{Cl}$ : 7.5-43.7). Stable disease ( $\geq 8$ weeks) was observed in 35\% (95\% Cl: 16.4-57.3) of PC patients. The median PFS was 4.6 months. The mOS was 9.8 months. The most common adverse event involved fatigue, nausea and vomiting [63]. Olaparib is also studied in phase II trials in U.S and Israel (NCT02677038, NCT02511223) among 32 patients with metastatic $P C$ and the BRCAness phenotype but without the germline BRCA1/2 mutation, who received at least one prior therapy. The antitumour activity was seen only in platinum-sensitive patients. The median PFS varies between 14 weeks (range: 5.7-40 weeks) in the Israel part of the study and 24.7 weeks (range: 3.9-41.1 weeks) in the U.S. group [64].

The POLO, a randomized, placebo-controlled phase III trial (NCT02184195), evaluated the role of olaparib as a maintained treatment among 154 enrolled patients with metastatic PC and deleterious/suspected deleterious germline BRCA1/2 mutation that had not progressed within 16 weeks during the first-line platinum-based chemotherapy (mainly folfirinox). The patients were divided into two groups, the first was given olaparib 300 mg twice a day $(n=92)$, the second received a placebo $(n=62)$.
The primary endpoint measure was PFS. The main secondary endpoint measure was the OS, time from randomization to the second progression, safety and tolerability. Initially, it was published that olaparib treatment significantly prolonged PFS in comparison to the placebo (7.4 vs. 3.8 months; $H R=0.53$, $\mathrm{p}=0.0038)$. Recently, on the ASCO Gastrointestinal Cancers Symposium 2021, the newest result data were shown. The OS analysis shows that the OS for the olaparib group was 19 vs. 19.2 months for placebo, which failed to be statistically significant (HR: 0.83; $p=0.3487$ ), however, $33.9 \%$ of patients who received PARPi survived 3 years vs. $17.8 \%$ in the placebo group. The most common ( $\geq 15 \%)$ adverse events in the olaparib group across all grades were nausea, fatigue and diarrhoea. Anemia was the most common AE grade 3 in the study group $[14,65]$.

The NCT03140670 phase II study is evaluating Rucaparib among patients with metastatic or locally advanced PC and germline, somatic BRCA1/2, or PALB2 mutation. The primary outcome measure is the number of adverse events. The initial results showed that the median PFS was 9.1 months and the ORR of $36.8 \%$ [66].

Veliparib was studied, in phase II trials in patients with germline BRCA1/2 or the PALB2 mutation and stage III and IV $P C$. The enrolled patients were treated with $1-2$ previous chemotherapy regimen. The response rate was not confirmed. The mPFS was 1.7 ms (95\% Cl: 1.57-1.83) and mOS was 3.1 ms [67].

The results of clinical studies with drugs other than olaparib are limited. The currently ongoing clinical trials try to determine the biomarkers, the role of genes other than BRCA mutated genes and proper sequention of treatment. Among them, one of the most interesting studies is the APOLLO trial (NCT04858334) a phase II, randomized trial that determines the RFS benefit from the maintenance of olaparib therapy following chemotherapy in patients with resected $P C$ and a pathogenic germline or somatic BRCA1/2, PALB2 mutation. 
The LODESTAR, a phase II study (NCT04171700) is evaluating the rucaparib in patients with solid tumours and with deleterious mutations in HRR genes. Patients enrolled to the study had solid tumors with the BRCA1/2, PALB2, RAD51C, RAD51D, BARD1, BRIP1, FANC, NBN, RAD51, or RAD51B mutation. The primary outcome measure is the best overall response rate. Niraparib is also being studied in a phase II trial (NCT03601923) among patients with the BRCA1, BRCA2, PALB2, CHEK2, or ATM mutation and advanced $P C$ that is not curable with standard approaches. Talazoparib in monotherapy is studied in two clinical trials. The NCT04550494 trial is the II phase trial that evaluates the pharmacodynamic of PARPi in patients with advanced cancers and mutations in DDR genes. The NCT01286987 trials are a phase I study that evaluates the number of participants with objective response among patients with advanced or recurrent tumours.

PARPi are also being tested in polytherapy with other drugs. It has been hypothesized that combined therapy, especially with chemotherapy, may provide a synergistic therapeutic strategy for patients with PC. The rationale of this combination with a platinum is based on e.g. increased DNA damage by chemotherapy [68]. Initial results come from a phase I trial which assessed the combination of veliparib, gemcitabine and cisplatinin patients with BRCA1/2 mutated and wild-type PC. The response rate within the BRCA mutated cohort was $77.8 \%$. The mOS of patients with BRCA1/2-mutated PC and patients with wild-type PC was 23,3 months and 11 months respectively [69]. These promising results led to a phase II, randomized trial. Patients with BRCA1/2 or PALB2-mutated PC were treated with gemcitabine and cisplatin chemotherapy with or without veliparib. The authors found non-significant benefit in the response rate between these two groups (74.1\% in arm with veliparib vs. 65.2\% in chemotherapy arm; $p=0.55)$ [70]. The trials did not show a survival benefit in mPFS (10.1 months for arm with veliparib (95\% Cl: 6.7-11.5 months) vs. 9.7 months for chemotherapy (95\% Cl: 4.2-13.6 months; $p=0.73$ ). Median OS for veliparib and chemotherapy cohort was 15.5 months ( $95 \% \mathrm{Cl}$ : 12.2-24.3 months) vs. 16.4 months for chemotherapy ( $95 \% \mathrm{Cl}: 11.7-23.4$ months; $\mathrm{p}=0.6)$.

Currently, there are more clinical trials testing PARPi with chemotherapy mainly based on irinotecan-based chemotherapy regimens like (NCT03337087, NCT02890355, NCT00576654, NCT04228601) and cisplatin (NCT01585805). The PARPi are being tested with targeted therapy like cediranib (inhibitor of vascular endothelial growth factor receptor tyrosine kinases; NCT02498613), AZD6738 (ATR kinase inhibitor; NCT03682289), immunotherapy: pembrolizumab (anti-PD1 inhibitor; NCT04548752), dostarlimab (anti-PD1 inhibitor; NCT04493060, NCT04673448), nivolumab (anti-PD1 inhibitor; NCT03404960), ipilimumab (anti-CTLA4; NCT03404960). In addition, the new PARPi are being tested like AMXI-5001, an orally available dual PARP and microtubule polymerization inhibitor (NCT04503265), AZD5305 (NCT04644068) or NMS03305293 (NCT04182516).

\section{Conclusions}

Pancreatic cancer remains one of the deadliest neoplasms with poor survival rates. There is a high need for new therapeutic regimens which improve the clinical outcomes of patients. In recent years, thanks to a deeper understanding of the molecular and genetic landscape of PC, PARPi has also emerged as a novel class of targeted therapy for patients with PC.

PARPi is a new class of drugs based on gene profiling that is currently being studied in PC. Many clinical trials are ongoing to determine the role of drugs in monotherapy and polytherapy. Despite that, the POLO trial did not show that olaparib increases the OS, yet many questions remain regarding the genetic status, role of other HRR genes in PC treatment and sequential treatment strategy. The new direction in $P C$ treatment is signalling pathway inhibitors, immunotherapy agents, drugs targeting the metabolism of tumours and drugs targeting the tumour microenvironment, which could be studied as polytherapy with PARPi [71]. A better understanding of the action and responses at the molecular level of PC cells and the implementation of routine genetic testing in patients have the potential to reveal novel treatment opportunities and thus may broaden the treatment for patients with actionable aberrations [71]. NCCN recommends gene profiling for patients with locally advanced/metastatic PC. The testing should be performed to identify fusions (ALK [anaplastic lymphoma kinase], NRG1 [neuregulin1], NTRK [neurotrophic receptor tyrosine kinase 1], ROS1 [c-Ros Oncogene 1]), mutations (BRAF, BRCA1/2, HER2 [human epidermal growth factor receptor 2], KRAS, PALB2), and MMR deficiency [72]. The recommended material for study is the tumour tissue or, if not available, the cell-free DNA. The preferred technique includes immunohistochemistry, polymerase chain reaction, or next-generation sequencing. Molecular tumour profiling is the future of personalized therapy in pancreatic cancer treatment, which may finally improve the survival rates of patients.

\section{Conflict of interest: none declared}

\author{
Dawid Sigorski \\ University of Warmia and Mazury in Olsztyn \\ Collegium Medicum \\ Department of Oncology \\ ul. M. Oczapowskiego 2 \\ 10-714 Olsztyn, Poland \\ e-mail:dawid.sigorski@uwm.edu.pl
}

Received: 18 Aug 2021

Accepted: 21 Dec 2021

\section{References}

1. Society. AC. Facts \& Figures 2021. American Cancer Society.

2. Ducreux M, Cuhna ASa, Caramella C, et al. ESMO Guidelines Committee. Cancer of the pancreas: ESMO Clinical Practice Guidelines for diagnosis, treatment and follow-up. Ann Oncol. 2015; 26 Suppl 5: v56-v68, doi: 10.1093/annonc/mdv295, indexed in Pubmed: 26314780. 
3. Springfeld C, Jäger $D$, Büchler MW, et al. Chemotherapy for pancreatic cancer. Presse Med. 2019; 48(3 Pt 2): e159-e174, doi: 10.1016/j. Ipm.2019.02.025, indexed in Pubmed: 30879894.

4. Piątek M, Nawrocki S. Locally advanced pancreatic cancer - new therapeutic challenges. Nowotwory. Journal of Oncology. 2016; 66(4): 312-316, doi: 10.5603/njo.2016.0059.

5. Aguilar-Quesada R, Muñoz-Gámez JA, Martín-Oliva D, et al. Modulation of transcription by PARP-1: consequences in carcinogenesis and inflammation. Curr Med Chem. 2007; 14(11): 1179-1187, doi: 10.2174/092986707780597998, indexed in Pubmed: 17504138.

6. Martínez-Bosch N, Fernández-Zapico ME, Navarro P, et al. Poly(ADP-Ribose) Polymerases: New Players in the Pathogenesis of Exocrine Pancreatic Diseases. Am J Pathol. 2016; 186(2): 234-241, doi: 10.1016/j. ajpath.2015.09.021, indexed in Pubmed: 26687988.

7. Sigorski D, Iżycka-Świeszewska E, Bodnar L. Poly(ADP-Ribose) Polymerase Inhibitors in Prostate Cancer: Molecular Mechanisms, and Preclinical and Clinical Data. Target Oncol. 2020; 15(6): 709-722, doi: 10.1007/ s11523-020-00756-4, indexed in Pubmed: 33044685.

8. Pujade-Lauraine E, Ledermann J, Selle F, et al. Olaparib tablets as maintenance therapy in patients with platinum-sensitive, relapsed ovarian cancer and a BRCA1/2 mutation (SOLO2/ENGOT-Ov21): a double-blind, randomised, placebo-controlled, phase 3 trial. Lancet Oncol. 2017; 18(9): 1274-1284, doi: 10.1016/s1470-2045(17)30469-2.

9. Coleman RL, Sill MW, Bell-McGuinn K, et al. A phase II evaluation of the potent, highly selective PARP inhibitor veliparib in the treatment of persistent or recurrent epithelial ovarian, fallopian tube, or primary peritoneal cancer in patients who carry a germline BRCA1 or BRCA2 mutation - An NRG Oncology/Gynecologic Oncology Group study. Gynecol Oncol. 2015; 137(3): 386-391, doi: 10.1016/j.ygyno.2015.03.042, indexed in Pubmed: 25818403.

10. Litton JK, Rugo HS, Ettl J, et al. Talazoparib in Patients with Advanced Breast Cancer and a Germline BRCA Mutation. N Engl J Med. 2018; 379(8): 753-763, doi: 10.1056/NEJMoa1802905, indexed in Pubmed: 30110579.

11. Mateo J, Porta N, Bianchini D, et al. Olaparib in patients with metastatic castration-resistant prostate cancer with DNA repair gene aberrations (TOPARP-B): a multicentre, open-label, randomised, phase 2 trial. Lancet Oncol. 2020; 21(1): 162-174, doi: 10.1016/S1470-2045(19)30684-9, indexed in Pubmed: 31806540.

12. Doraczyńska-Kowalik A, Janus-Szymańska G, Matkowski R, et al. Genetyka i onkologia (część 2.). Podstawy medycyny personalizowanej w leczeniu raka piersi i raka jajnika. Nowotwory. Journal of Oncology. 2020; 70(5): 187-202, doi: 10.5603/njo.2020.0040.

13. Food and Drug Administration. FDA approves olaparib for gBRCAm metastatic pancreatic adenocarcinoma. 2020.

14. Golan T, Hammel P, Reni M, et al. Maintenance Olaparib for Germline -Mutated Metastatic Pancreatic Cancer. N Engl J Med. 2019; 381(4): 317-327, doi: 10.1056/NEJMoa1903387, indexed in Pubmed: 31157963.

15. Hanahan D, Weinberg RA. Hallmarks of cancer: the next generation. Cell. 2011; 144(5): 646-674, doi: 10.1016/j.cell.2011.02.013, indexed in Pubmed: 21376230.

16. Goral V. Pancreatic Cancer: Pathogenesis and Diagnosis. Asian Pac J Cancer Prev. 2015; 16(14): 5619-5624, doi: 10.7314/apjcp.2015.16.14.5619, indexed in Pubmed: 26320426.

17. Hu C, Hart SN, Polley EC, et al. Association Between Inherited Germline Mutations in Cancer Predisposition Genes and Risk of Pancreatic Cancer. JAMA. 2018; 319(23):2401-2409, doi: 10.1001/jama.2018.6228, indexed in Pubmed: 29922827.

18. Bailey P, Chang DK, Nones K, et al. Australian Pancreatic Cancer Genome Initiative. Genomic analyses identify molecular subtypes of pancreatic cancer. Nature. 2016; 531(7592): 47-52, doi: 10.1038/nature16965, indexed in Pubmed: 26909576.

19. Waddell N, Pajic M, Patch AM, et al. Australian Pancreatic Cancer Genome Initiative. Whole genomes redefine the mutational landscape of pancreatic cancer. Nature. 2015; 518(7540): 495-501, doi: 10.1038/ nature14169, indexed in Pubmed: 25719666.

20. Rondinelli B, Gogola E, Yücel H, et al. EZH2 promotes degradation of stalled replication forks by recruiting MUS81 through histone $\mathrm{H} 3$ trimethylation. Nat Cell Biol. 2017; 19(11): 1371-1378, doi: 10.1038/ ncb3626, indexed in Pubmed: 29035360.

21. Chaudhuri AR, Callen E, Ding $X$, et al. Replication fork stability confers chemoresistance in BRCA-deficient cells. Nature. 2016; 535(7612): 382-387, doi: 10.1038/nature18325.

22. Li X, Heyer WD. Homologous recombination in DNA repair and DNA damage tolerance. Cell Res. 2008; 18(1): 99-113, doi: 10.1038/cr.2008.1, indexed in Pubmed: 18166982.
23. Moynahan ME, Jasin M. Mitotic homologous recombination maintains genomic stability and suppresses tumorigenesis. Nat Rev Mol Cell Biol. 2010; 11(3): 196-207, doi: 10.1038/nrm2851, indexed in Pubmed: 20177395

24. Lohse I, Kumareswaran R, Cao P, et al. Effects of Combined Treatment with lonizing Radiation and the PARP Inhibitor Olaparib in BRCA Mutant and Wild Type Patient-Derived Pancreatic Cancer Xenografts. PLoS One. 2016; 11(12): e0167272, doi: 10.1371/journal.pone.0167272, indexed in Pubmed: 28033382.

25. Pilarski R. The Role of Testing in Hereditary Pancreatic and Prostate Cancer Families. Am Soc Clin Oncol Educ Book. 2019; 39: 79-86, doi: 10.1200/EDBK_238977, indexed in Pubmed: 31099688.

26. Yadav S, Kasi PM, Bamlet WR, et al. Effect of Germline Mutations in Homologous Recombination Repair Genes on Overall Survival of Patients with Pancreatic Adenocarcinoma. Clin Cancer Res. 2020; 26(24): 6505-6512, doi: 10.1158/1078-0432.CCR-20-1788, indexed in Pubmed: 33028596.

27. Golan T, Kanji ZS, Epelbaum R, et al. Overall survival and clinical characteristics of pancreatic cancer in BRCA mutation carriers. $\mathrm{Br}$ J Cancer. 2014; 111(6): 1132-1138, doi: 10.1038/bjc.2014.418, indexed in Pubmed: 25072261.

28. Lowery MA, Jordan EJ, Basturk O, et al. Real-Time Genomic Profiling of Pancreatic Ductal Adenocarcinoma: Potential Actionability and Correlation with Clinical Phenotype. Clin Cancer Res. 2017; 23(20): 6094-6100, doi: 10.1158/1078-0432.CCR-17-0899, indexed in Pubmed: 28754816.

29. Southey MC, Goldgar DE, Winqvist R, et al. Australian Ovarian Cancer Study Group. PALB2, CHEK2 and ATM rare variants and cancer risk: data from COGS. J Med Genet. 2016; 53(12): 800-811, doi: 10.1136/ jmedgenet-2016-103839, indexed in Pubmed: 27595995.

30. Sehdev A, Gbolahan O, Hancock BA, et al. Germline and Somatic DNA Damage Repair Gene Mutations and Overall Survival in Metastatic Pancreatic Adenocarcinoma Patients Treated with FOLFIRINOX. Clin Cancer Res. 2018; 24(24): 6204-6211, doi: 10.1158/1078-0432.CCR-181472, indexed in Pubmed: 30131383.

31. Lord C, Ashworth A. BRCAness revisited. Nature Reviews Cancer. 2016; 16(2): 110-120, doi: 10.1038/nrc.2015.21.

32. Holter S, Borgida A, Dodd A, et al. Germline BRCA Mutations in a Large Clinic-Based Cohort of Patients With Pancreatic Adenocarcinoma. J Clin Oncol. 2015; 33(28): 3124-3129, doi: 10.1200/JCO.2014.59.7401, indexed in Pubmed: 25940717.

33. Chaffee KG, Oberg AL, McWilliams RR, et al. Prevalence of germ-line mutations in cancer genes among pancreatic cancer patients with a positive family history. Genet Med. 2018; 20(1): 119-127, doi: 10.1038/ gim.2017.85, indexed in Pubmed: 28726808.

34. Nanda N, Roberts NJ. Serine/Threonine Kinase and its Role in Pancreatic Risk. Genes (Basel). 2020; 11(1), doi: 10.3390/genes11010108, indexed in Pubmed: 31963441.

35. Roberts NJ, Jiao Y, Yu J, et al. ATM mutations in patients with hereditary pancreatic cancer. Cancer Discov. 2012; 2(1): 41-46, doi: 10.1158/21598290.CD-11-0194, indexed in Pubmed: 22585167.

36. Grant RC, Selander I, Connor AA, et al. Prevalence of germline mutations in cancer predisposition genes in patients with pancreatic cancer. Gastroenterology. 2015; 148(3): 556-564, doi: 10.1053/j. gastro.2014.11.042, indexed in Pubmed: 25479140.

37. Mandelker D, Zhang L, Kemel Y, et al. Mutation Detection in Patients With Advanced Cancer by Universal Sequencing of Cancer-Related Genes in Tumor and Normal DNA vs Guideline-Based Germline Testing. JAMA. 2017; 318(9): 825-835, doi: 10.1001/jama.2017.11137, indexed in Pubmed: 28873162.

38. Ayars M, Eshleman J, Goggins M. Susceptibility of ATM-deficient pancreatic cancer cells to radiation. Cell Cycle. 2017; 16(10): 991-998, doi: 10.1080/15384101.2017.1312236, indexed in Pubmed: 28453388.

39. Wang Y, Kuramitsu Y, Tokuda K, et al. Gemcitabine induces poly (ADP-ribose) polymerase-1 (PARP-1) degradation through autophagy in pancreatic cancer. PLoS One. 2014; 9(10): e109076, doi: 10.1371/journal. pone.0109076, indexed in Pubmed: 25271986.

40. Perkhofer L, Schmitt A, Romero Carrasco MC, et al. ATM Deficiency Generating Genomic Instability Sensitizes Pancreatic Ductal Adenocarcinoma Cells to Therapy-Induced DNA Damage. Cancer Res. 2017; 77(20): 5576-5590, doi: 10.1158/0008-5472.CAN-17-0634, indexed in Pubmed: 28790064.

41. Lord CJ, Ashworth A. PARP inhibitors: Synthetic lethality in the clinic. Science. 2017; 355(6330): 1152-1158, doi: 10.1126/science.aam7344, indexed in Pubmed: 28302823.

42. McCabe N, Turner NC, Lord CJ, et al. Deficiency in the repair of DNA damage by homologous recombination and sensitivity to 
poly(ADP-ribose) polymerase inhibition. Cancer Res. 2006; 66(16): 8109-8115, doi: 10.1158/0008-5472.CAN-06-0140, indexed in Pubmed: 16912188.

43. Marteijn JA, Lans $\mathrm{H}$, Vermeulen W, et al. Understanding nucleotide excision repair and its roles in cancer and ageing. Nat Rev Mol Cell Biol. 2014; 15(7): 465-481, doi: 10.1038/nrm3822, indexed in Pubmed: 24954209.

44. Li GM. DNA Mismatch Repair and the DNA Damage Response. Encyclopedia of Biological Chemistry. 2013: 51-53, doi: 10.1016/b978-0-12378630-2.00238-3.

45. Wong W, Raufi AG, Safyan RA, et al. BRCA Mutations in Pancreas Cancer: Spectrum, Current Management, Challenges and Future Prospects. Cancer Manag Res. 2020; 12: 2731-2742, doi: 10.2147/CMAR.S211151, indexed in Pubmed: 32368150.

46. Plummer R. Perspective on the pipeline of drugs being developed with modulation of DNA damage as a target. Clin Cancer Res. 2010; 16(18): 4527-4531, doi: 10.1158/1078-0432.CCR-10-0984, indexed in Pubmed: 20823148

47. Lee MV, Katabathina VS, Bowerson ML, et al. BRCA-associated Cancers: Role of Imaging in Screening, Diagnosis, and Management. Radiographics. 2017; 37(4): 1005-1023, doi: 10.1148/rg.2017160144, indexed in Pubmed: 28548905.

48. Peralta-Leal A, Rodríguez MI, Oliver FJ. Poly(ADP-ribose)polymerase-1 (PARP-1) in carcinogenesis: potential role of PARP inhibitors in cancer treatment. Clin TransI Oncol. 2008; 10(6):318-323, doi: 10.1007/s12094008-0207-8, indexed in Pubmed: 18558578.

49. Virág L. Structure and function of poly(ADP-ribose) polymerase-1: role in oxidative stress-related pathologies. Curr Vasc Pharmacol. 2005; 3(3): 209-214, doi: 10.2174/1570161054368625, indexed in Pubmed: 16026317.

50. Otto H, Reche PA, Bazan F, et al. In silico characterization of the family of PARP-like poly(ADP-ribosyl)transferases (pARTs). BMC Genomics. 2005; 6: 139, doi: 10.1186/1471-2164-6-139, indexed in Pubmed: 16202152.

51. de Murcia JM, Niedergang C, Trucco C, et al. Requirement of poly(ADP-ribose) polymerase in recovery from DNA damage in mice and in cells. Proc Natl Acad Sci U S A. 1997; 94(14): 7303-7307, doi: 10.1073/ pnas.94.14.7303, indexed in Pubmed: 9207086.

52. Martínez-Bosch N, Iglesias M, Munné-Collado J, et al. Parp-1 genetic ablation in Ela-myc mice unveils novel roles for Parp-1 in pancreatic cancer. J Pathol. 2014; 234(2): 214-227, doi: 10.1002/path.4384, indexed in Pubmed: 24889936.

53. Hou Z, Cui Y, Xing H, et al. Down-expression of poly(ADP-ribose) polymerase in p53-regulated pancreatic cancer cells. Oncol Lett. 2018; 15(2): 1943-1948, doi: 10.3892/ol.2017.7500, indexed in Pubmed: 29434894.

54. Wang $\mathrm{M}, \mathrm{Wu} \mathrm{W}, \mathrm{Wu} \mathrm{W}$, et al. PARP-1 and Ku compete for repair of DNA double strand breaks by distinct NHEJ pathways. Nucleic Acids Res. 2006; 34(21): 6170-6182, doi: 10.1093/nar/gkl840, indexed in Pubmed: 17088286

55. Pilié PG, Tang C, Mills GB, et al. State-of-the-art strategies for targeting the DNA damage response in cancer. Nat Rev Clin Oncol. 2019; 16(2): 81-104, doi: 10.1038/s41571-018-0114-z, indexed in Pubmed: 30356138.

56. Dedes KJ, Wilkerson PM, Wetterskog D, et al. Synthetic lethality of PARP inhibition in cancers lacking BRCA1 and BRCA2 mutations. Cell Cycle. 2011; 10(8): 1192-1199, doi: 10.4161/cc.10.8.15273, indexed in Pubmed: 21487248.

57. Xu F, Sun Y, Yang SZ, et al. Cytoplasmic PARP-1 promotes pancreatic cancer tumorigenesis and resistance. Int J Cancer. 2019; 145(2): 474-483, doi: 10.1002/ijc.32108, indexed in Pubmed: 30614530.

58. Toma M, Skorski T, Śliwiński T. Synthetic lethality as a functional tool in basic research and in anticancer therapy. Postepy Hig Med Dosw. 2014; 68: 1091-1103, doi: 10.5604/17322693.1119792.
59. Bryant HE, Schultz N, Thomas HD, et al. Specific killing of BRCA2-deficient tumours with inhibitors of poly(ADP-ribose) polymerase. Nature. 2005; 434(7035): 913-917, doi: 10.1038/nature03443, indexed in Pubmed: 15829966.

60. Farmer $\mathrm{H}, \mathrm{McC}$ abe $\mathrm{N}$, Lord $\mathrm{CJ}$, et al. Targeting the DNA repair defect in BRCA mutant cells as a therapeutic strategy. Nature. 2005; 434(7035): 917-921, doi: 10.1038/nature03445, indexed in Pubmed: 15829967.

61. Klauschen $F$, von Winterfeld M, Stenzinger A, et al. High nuclear poly-(ADP-ribose)-polymerase expression is prognostic of improved survival in pancreatic cancer. Histopathology. 2012; 61(3): 409-416, doi: 10.1111/j.1365-2559.2012.04225.x, indexed in Pubmed: 22384823.

62. Gonçalves A, Finetti P, Sabatier R, et al. Poly(ADP-ribose) polymerase- 1 mRNA expression in human breast cancer: a meta-analysis. Breast Cancer Res Treat. 2011; 127(1): 273-281, doi: 10.1007/s10549-010-1199-y, indexed in Pubmed: 21069454.

63. Kaufman B, Shapira-Frommer R, Schmutzler RK, et al. Olaparib monotherapy in patients with advanced cancer and a germline BRCA1/2 mutation. J Clin Oncol. 2015; 33(3): 244-250, doi: 10.1200/ JCO.2014.56.2728, indexed in Pubmed: 25366685.

64. Golan T, Varadhachary G, Sela T, et al. Phase II study of olaparib for BRCAness phenotype in pancreatic cancer. J Clin Oncol. 2018; 36(4_suppl): 297-297, doi: 10.1200/jco.2018.36.4_suppl.297.

65. Golan $T$, Hammel $P$, Reni $M$, et al. Overall survival from the phase 3 POLO trial: Maintenance olaparib for germline BRCA-mutated metastatic pancreatic cancer. J Clin Oncol. 2021; 39(3 suppl): 378-378, doi: 10.1200/jco.2021.39.3_suppl.378.

66. Reiss KA, Mick R, O'Hara MH, et al. Phase II Study of Maintenance Rucaparib in Patients With Platinum-Sensitive Advanced Pancreatic Cancer and a Pathogenic Germline or Somatic Variant in , , or . J Clin Oncol. 2021; 39(22): 2497-2505, doi: 10.1200/JCO.21.00003, indexed in Pubmed: 33970687.

67. Lowery MA, Kelsen DP, Capanu M, et al. Phase II trial of veliparib in patients with previously treated BRCA-mutated pancreas ductal adenocarcinoma. Eur J Cancer. 2018; 89: 19-26, doi: 10.1016/j.ejca.2017.11.004, indexed in Pubmed: 29223478.

68. Matulonis UA, Monk BJ. PARP inhibitor and chemotherapy combination trials for the treatment of advanced malignancies: does a development pathway forward exist? Ann Oncol. 2017; 28(3): 443-447, doi: 10.1093/ annonc/mdw697, indexed in Pubmed: 28057663.

69. O'Reilly EM, Lee JW, Lowery MA, et al. Phase 1 trial evaluating cisplatin gemcitabine, and veliparib in 2 patient cohorts: Germline BRCA mutation carriers and wild-type BRCA pancreatic ductal adenocarcinoma. Cancer. 2018; 124(7): 1374-1382, doi: 10.1002/cncr.31218, indexed in Pubmed: 29338080.

70. O'Reilly EM, Lee JW, Zalupski M, et al. Randomized, Multicenter, Phase II Trial of Gemcitabine and Cisplatin With or Without Veliparib in Patients With Pancreas Adenocarcinoma and a Germline Mutation. J Clin Oncol. 2020; 38(13): 1378-1388, doi: 10.1200/JCO.19.02931, indexed in Pubmed: 31976786.

71. Nevala-Plagemann C, Hidalgo M, Garrido-Laguna I. From state-of-the-art treatments to novel therapies for advanced-stage pancreatic cancer. Nat Rev Clin Oncol. 2020; 17(2): 108-123, doi: 10.1038/s41571019-0281-6, indexed in Pubmed: 31705130.

72. Tempero MA, Malafa MP, Al-Hawary M, et al. Pancreatic Adenocarcinoma, Version 2.2021, NCCN Clinical Practice Guidelines in Oncology. J Nat Compr Canc Netw. 2021; 19(4): 439-457, doi: 10.6004/jnccn.2021.0017, indexed in Pubmed: 33845462.

73. Takeuchi S, Doi M, Ikari N, et al. Mutations in BRCA1, BRCA2, and PALB2, and a panel of 50 cancer-associated genes in pancreatic ductal adenocarcinoma. Sci Rep. 2018; 8(1): 8105, doi: 10.1038/s41598-018-26526-X, indexed in Pubmed: 29802286. 